\title{
PENGARUH DEBT TO EQUITY RATIO TERHADAP RETURN ON ASSET PADA PT. SURYO TOTO INDONESIA TBK PERIODE 2010-2019
}

\author{
1*Parmuji, 2 Irfan Rizka Akbar \\ ${ }_{1}$ STIE Hidayatullah, Depok, Jawa Barat, Indonesia \\ 2Universitas Pamulang, Tangerang Selatan, Banten, Indonesia \\ *parmuji@stiehidayatullah.ac.id
}

\begin{abstract}
Abstrak
Penelitian ini bertujuan untuk mengetahui pengaruh Debt to Equity Ratio terhadap Return on Asset pada PT. Suryo Toto Indonesia Tbk. Metode yang digunakan adalah explanatory research. Teknik analisis menggunakan analisis statistik dengan pengujian regresi, korelasi, determinasi dan uji hipotesis. Hasil penelitian ini variabel Debt to Equity Ratio diperoleh nilai rata-rata sebesar 7,72\%. Variabel Return on Asset diperoleh nilai rata-rata 0,62\%. Debt to Equity Ratio berpengaruh positif dan signifikan terhadap Return on Asset dengan nilai persamaan regresi $Y=2,109-0,192 X$, dan nilai koefisien korelasi -0,778 atau memiliki tingkat hubungan yang kuat dengan nilai determinasi 60,5\%. Uji hipotesis diperoleh signifikansi $0,000<0,05$.
\end{abstract}

Kata Kunci: Debt to Equity Ratio, Return on Asset.

\begin{abstract}
This study aims to determine the effect of Debt to Equity Ratio on Return on Assets at PT. Suryo Toto Indonesia Tbk. The method used is explanatory research. The analysis technique uses statistical analysis with regression testing, correlation, determination and hypothesis testing. The results of this study, the variable Debt to Equity Ratio obtained an average value of 7.72\%. The return on asset variable obtained an average value of $0.62 \%$. Debt to Equity Ratio has a positive and significant effect on Return on Assets with a regression equation value of $Y=2.109$ $0.192 X$, and a correlation coefficient value of -0.778 or has a strong level of relationship with a determination value of $60.5 \%$. Hypothesis testing obtained a significance of $0.000<0.05$.
\end{abstract}

Keywords: Debt to Equity Ratio, Return on Assets.

\section{PENDAHULUAN}

Dengan memperoleh laba yang maksimal seperti yang telah ditargetkan oleh perusahaan dapat berbuat banyak bagi kesejahteraan pemilik, karyawan, serta meningkatkan mutu produk dan melakukan investasi baru. Oleh karena itu, manajemen perusahaan dalam praktiknya dituntut harus mampu untuk memenuhi target yang telah ditetapkan. Untuk mengukur tingkat keuntungan suatu perusahaan, digunakan rasio keuntungan atau rasio profitabilitas.

Bagi suatu perusahaan untuk memperoleh laba yang semaksimal mungkin, dapat dilakukan dengan memperbesar jumlah produksi yang dapat dijual. Salah satu faktor produksi terpenting ialah modal kerja yang digunakan perusahaan untuk membiayai operasi perusahaan demi menjamin kelangsungan hidup perusahaan. Maka dari itu, manajer keuangan harus mampu merencanakan dengan baik besarnya jumlah modal kerja yang efektif dan efisien di masa mendatang. Analisis keuangan yang mencakup rasio keuangan, analisis kelemahan dan kekuatan dibidang finansial akan sangat membantu dalam menilai prestasi manajemen masa lalu dan prospeknya dimasa datang. Dengan menganalisis prestasi keuangan, seorang analisis keuangan akan dapat menilai apakah manajer keuangan dapat merencanakan dan mengimplementasikan kedalam setiap tindakan secara konsisten dengan tujuan memaksimumkan kemakmuran pemegang saham.

Penggunaan analisis rasio keuangan ini sangat bervariasi dan tergantung oleh pihak yang memerlukan. Disamping itu juga perlu disadari bahwa analisa rasio keuangan hanya memberikan gambaran satu sisi saja, oleh sebab itu masih diperlukan lagi tambahan data agar dapat lebih baik. Akhirnya analisis rasio keuangan hanya bermanfaat apabila dibandingkan standar yang jelas, seperti 
standar industri, kecenderungan atau standar tertentu sebagai tujuan manajemen. Selain itu perlu diperhatikan apabila membandingkan rasio satu perusahaan dengan perusahaan lain adalah menyangkut sistem akuntansi yang digunakan, kemampuan perusahaan memperoleh laba dalam hubungannya dengan penjualan, total aktiva maupun modal sendiri. Dengan demikian bagi investor jangka panjang akan sangat berkepentingan dengan analisis profitabilitas ini misalnya bagi pemegang saham akan melihat keuntungan yang benar-benar akan diterima dalam bentuk dividen (Agus Sartono, 2008).

Dalam memaksimumkan keuntungan selalu ada pertukaran dengan risiko. Semakin besar risiko yang dihadapi akan semakin besar pula keuntungan yang diharapkan. Seumpama kita diminta memilih antara dua proyek yang mempunyai risiko yang sama, kita akan memilih proyek yang akan memberikan imbalan atau perolehan yang lebih besar. Namun situasi yang sering dihadapi adalah apakah perolehan yang akan diterima cukup memadai untuk menutup risiko yang dihadapi. Pola yang dikembangkan untuk mengatasi masalah keuntungan dan risiko adalah memaksimumkan laba (maximize profit) disamping meminimumkan risiko (minimizing risk) (Budi Raharjo, 2007). Profitabilitas menggambarkan kemampuan perusahaan untuk mendapatkan laba melalui semua kemampuan dan sumber yang ada seperti kegiatan penjualan, kas, modal, jumlah karyawan, jumlah cabang dan sebagainya. Rasio profitabilitas mengukur efektivitas manajemen secara keseluruhan yang ditunjukkan dengan besar kecilnya tingkat keuntungan yang diperoleh dalam hubungannya dengan penjualan maupun investasi (Sofyan Syafri Harahap, 2002).

Perusahaan semakin tinggi rasio lancar, seharusnya semakin besar kemampuan untuk membayar tagihannya. Rasio ini harus dianggap sebagai ukuran besar karena tidak mempertimbangkan likuiditas komponen individual aktiva lancar.
Perusahaan dengan aktiva lancar terdiri dari kas dan piutang tanpa jatuh tempo biasanya dianggap lebih likuid daripada perusahaan yang aktiva lancarnya terdiri dari persediaan (Van Horn, James C dan John M Wachowiez, 2000).

Perusahaan dengan kewajiban yang terlampau banyak akan mengalami kesulitan untuk mendapatkan tambahan dana dari luar. Kewajiban bukan sesuatu yang jelek jika dapat memberikan keuntungan kepada pemiliknya. Jika kewajiban dimanfaatkan dengan efektif dan laba yang didapat cukup untuk membayar biaya bunga secara periodik, laba yang diberikan kepada para pemegang saham ini disebut Solvabilitas. Secara Bahasa Solvabilitas berarti pengungkit (alat ungkit). Jadi, jika diterapkan dalam istilah keuangan, dapat dikatakan bahwa dengan usaha sedikit akat diperoleh hasil yang besar. Solvabilitas tercipta pada waktu laba perusahaan lebih besar dari pada bunga pinjaman yang harus dibayarnya (Kuswadi, 2005).

Menurut Kasmir (2008) Ratio Solvabilitas adalah ratio yang digunakan untuk mengukur sejauh mana aktiva perusahaan dibiaya dengan hutang. Artinya berapa besar beban hutang yang ditanggung perusahaan dibandingkan dengan aktivanya.

Pembiayaan dengan utang atau Solvabilitas memiliki tiga implikasi penting, yaitu: Pertama, memperoleh dana melalui utang membuat pemegang saham dapat mempertahankan pengendalian atas perusahaan dengan investasi yang terbatas. Kedua, kreditur melihat ekuitas atau dana yang disetor pemilik untuk memberikan marjin pengaman, sehingga jika pemegang saham hanya memberikan sebagian kecil dari total pembiayaan, maka risiko perusahaan sebagian besar ada pada kreditur. Ketiga, Jika perusahaan memperoleh pengembalian yang lebih besar atas investasi yang dibiayai dengan dana pinjaman dibanding pembayaran bunga, maka pengembalian atas modal pemilik akan lebih besar (Brigham dan Houston, 2001). 

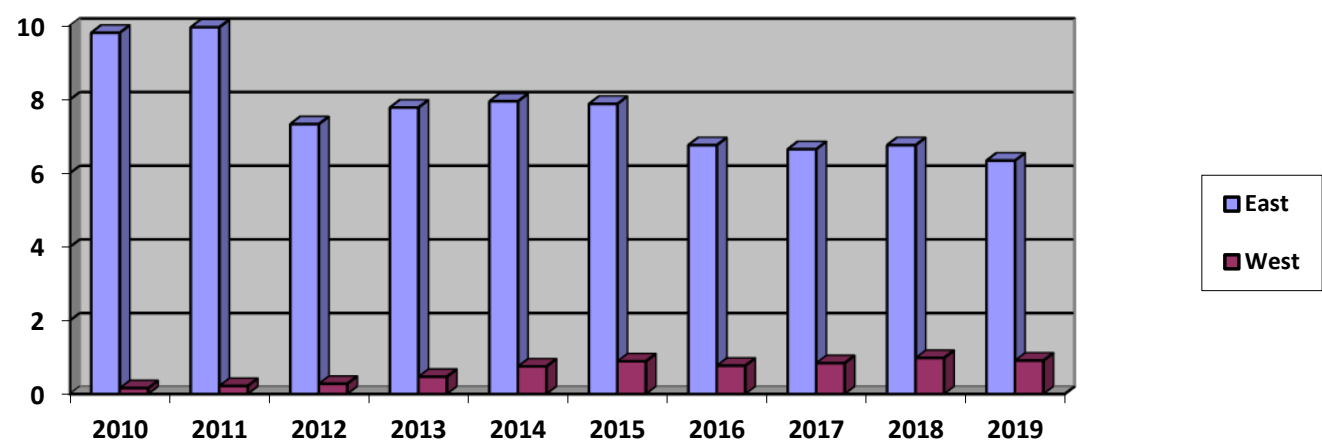

Gambar 1. Data Solvabilitas dan Profitabilitas PT. Surya Toto Indonesia, Tbk, Periode Tahun 2010-2019

Berdasarkan data pada grafik di atas menunjukkan bahwa tingkat liquiditas maupun profitabilitas PT. Suryo Toto Indonesia, Tbk tahun 2010-2019 mengalami perkembangan yang fluktuasi dengan capaian Debt to Equity Ratio rata-rata per tahun sebesar 6,76\% dan capaian Return on Asset rata-rata per tahun sebesar $0,63 \%$. Ketika profitabilitas perusahaan turun menandakan bahwa kinerja yang kurang baik dalam pencapaian laba perusahaan. Tetapi perusahaan masih dapat meningkatkan profitabilitas dengan cara memaksimal penggunaan hutang dalam menunjang yang terlihat dari solvabilitas sehingga dimana profitabilitas perusahaan akan meningkat seiring dengan peningkatan solvabilitas sebagaimana yang dinyatakan oleh I Made Sudana (2011:158) yang mengungkapkan bahwa Pengaruh hutang dalam pembelanjaan investasi perusahaan dapat mempengaruhi kemampuan perusahaan untuk menghasilkan laba atas modal yang digunakan (ROA).

Berdasarkan gambaran tersebut peneliti tertarik untuk meneliti mengenai "Pengaruh Rasio Solvabilitas Terhadap Rasioa Profitabilitas Pada PT. Suryo Toto Indonesia Tbk"

\section{METODE}

Populasi dalam penelitian ini laporan keuangan PT. Suryo Toto Indonesia Tbk selama 10 tahun. Teknik pengambilan sampling dalam penelitian ini adalah samplel jenuh, dimana semua anggota populasi dijadikan sebagai sampel. Dengan demikian sampel dalam penelitian ini laporan keuangan PT. Suryo Toto Indonesia Tbk selama 10 tahun. Jenis penelitian yang dipakai adalah asosiatif, dimana tujuannya adalah untuk mengetahui mencari keterhubungan antara variabel independen terhadap variabel dependennya. Dalam menganalisis data digunakan uji validitas, uji reliabilitas, analisis regresi linier sederhana, koefisien korelasi, koefisien determinasi dan uji hipotesis.

\section{HASIL DAN PEMBAHASAN}

\section{Analisis Deskriptif}

Pada pengujian ini digunakan untuk mengetahui skor minimum dan maksimum skor tertinggi, ratting score dan standar deviasi dari masing-masing variabel. Adapun hasilnya sebagai berikut:

Tabel 1. Hasil Analisis Descriptive Statistics

\begin{tabular}{lr|r|r|r|r} 
& \multicolumn{7}{c}{ Descriptive Statistics } & & \\
& $\mathrm{N}$ & \multicolumn{1}{c}{ Minimum } & Maximum & Mean & Std. Deviation \\
\hline Debt to Equity Ratio (X) & 10 & 6.34 & 9.96 & 7.7220 & 1.26984 \\
\hline Return on Asset (Y) & 10 & .16 & .98 & .6270 & .31334 \\
\hline Valid N (listwise) & 10 & & & & \\
\hline
\end{tabular}

Debt to Equity Ratio diperoleh nilai minimum sebesar $6,34 \%$ dan nilai maximum 9,96\% dengan rata-rata sebesar $7,72 \%$ dengan standar deviasi $1,26 \%$.
Return on Asset diperoleh nilai minimum sebesar 0,16 dan nilai maximum 0,98\% dengan rata-rata sebesar $0,62 \%$ dengan standar deviasi $0,31 \%$. 


\section{Analisis Verifikatif}

Pada analisis ini dimaksudkan untuk mengetahui pengaruh variabel independen terhadap variabel dependen. Adapun hasil pengujian sebagai berikut: a. Analisis Regresi Linier Sederhana

Uji regresi ini dimaksudkan untuk mengetahui perubahan variabel dependen jika variabel independen mengalami perubahan. Adapun hasil pengujiannya sebagai berikut:

Tabel 2. Hasil Pengujian Regresi Linier Sederhana

\begin{tabular}{lr|r|r|r|r} 
& \multicolumn{2}{c}{ Coefficients $^{\text {Un }} \begin{array}{l}\text { Unstandardized } \\
\text { Coefficients }\end{array}$} & $\begin{array}{l}\text { Standardized } \\
\text { Coefficients }\end{array}$ & & \\
Model & \multicolumn{1}{c}{ B } & Std. Error & Beta & t & Sig. \\
\hline 1 (Constant) & 2.109 & .428 & & 4.925 & .001 \\
\hline $\begin{array}{l}\text { Debt to Equity Ratio } \\
\text { (X) }\end{array}$ & -.192 & .055 & -.778 & -3.503 & .008 \\
\hline
\end{tabular}

Berdasarkan hasil pengujian pada tabel di atas, diperoleh persamaan regresi $Y=2,109-0,192 X$. Dari persamaan tersebut dijelaskan sebagai berikut:

1) Konstanta sebesar 2,109 diartikan jika Debt to Equity Ratio tidak ada, maka telah terdapat nilai Return on Asset sebesar 2,109 point.

2) Koefisien regresi Debt to Equity Ratio sebesar -0,192, angka ini negatif artinya setiap ada penurunan Debt to Equity Ratio

Tabel 3. Hasil Pengujian Koefisien Korelasi Debt to Equity Ratio Terhadap Return on Asset.

\section{Correlations $^{b}$}

\begin{tabular}{llr|r} 
& & $\begin{array}{c}\text { Debt to } \\
\text { Equity Ratio } \\
\text { (X1) }\end{array}$ & $\begin{array}{r}\text { Return on Asset } \\
\text { (Y) }\end{array}$ \\
\hline $\begin{array}{l}\text { Debt to Equity Ratio } \\
\text { (X) }\end{array}$ & Pearson Correlation & 1 & $-.778^{* *}$ \\
\cline { 2 - 4 } Return on Asset (Y) & Sig. (2-tailed) & & .008 \\
\cline { 2 - 4 } & Pearson Correlation & $-.778^{* *}$ & 1 \\
\hline
\end{tabular}

Berdasarkan hasil pengujian diperoleh nilai korelasi sebesar $-0,778$ artinya Debt to Equity Ratio memiliki hubungan yang kuat terhadap Return on Asset.

\section{c. Analisis Koefisien Determinasi}

Tabel 4. Hasil Pengujian Koefisien Determinasi Debt to Equity Ratio Terhadap Return on Asset.

Model Summary

\begin{tabular}{|c|c|c|c|c|}
\hline \multicolumn{5}{|c|}{ Model Summary } \\
\hline Model & $\mathrm{R}$ & R Square & $\begin{array}{l}\text { Adjusted R } \\
\text { Square }\end{array}$ & $\begin{array}{l}\text { Std. Error of the } \\
\text { Estimate }\end{array}$ \\
\hline 1 & $.778^{a}$ & .605 & .556 & .20879 \\
\hline
\end{tabular}

sebesar -0,192 point maka Return on Asset juga akan mengalami penurunan sebesar $-0,192$ point.

\section{b. Analisis Koefisien Korelasi}

Analisis koefisien korelasi dimaksudkan untuk mengetahui tingkt kekuatan hubungan dari variabel independen terhadap variabel dependen baik secara parsial maupun simultan. Adapun hasil pengujian sebagai berikut: 
Berdasarkan hasil pengujian diperoleh nilai determinasi sebesar 0,605 artinya Debt to Equity Ratio memiliki kontribusi pengaruh sebesar $60,5 \%$ terhadap Return on Asset.
Pengujian hipotesis dengan uji $t$ digunakan untuk mengetahui hipotesis mana yang diterima.

Rumusan hipotesis: Terdapat pengaruh yang negatif signifikan antara Debt to Equity Ratio terhadap Return on Asset.

\section{d. Uji Hipotesis}

Tabel 5. Hasil Uji Hipotesis Debt to Equity Ratio Terhadap Return on Asset.

\begin{tabular}{|c|c|c|c|c|c|}
\hline \multirow[b]{3}{*}{ Model } & \multicolumn{2}{|c|}{ Coefficients $^{\mathrm{a}}$} & \multirow{3}{*}{$\begin{array}{l}\text { Standardized } \\
\text { Coefficients } \\
\text { Beta }\end{array}$} & \multirow[b]{3}{*}{$\mathrm{t}$} & \multirow[b]{3}{*}{ Sig. } \\
\hline & \multicolumn{2}{|c|}{$\begin{array}{l}\text { Unstandardized } \\
\text { Coefficients }\end{array}$} & & & \\
\hline & $\mathrm{B}$ & Std. Error & & & \\
\hline 1 (Constant) & 2.109 & .428 & & 4.925 & .001 \\
\hline Debt to Equity Ratio (X) & -.192 & .055 & -.778 & -3.503 & .008 \\
\hline
\end{tabular}

Berdasarkan hasil pengujian pada tabel di atas, diperoleh nilai $t$ hitung $<\mathrm{t}$ tabel atau $(-3,506<2,306)$, dengan demikian hipotesis yang diajukan bahwa terdapat pengaruh yang negatif signifikan atara Debt to Equity Ratio terhadap Return on Asset diterima.

\section{Pembahasan Hasil Penelitian}

1. Kondisi Jawaban Responden Variabel Debt to Equity Ratio

Berdasarkan data empiris dan analisis data, variabel Debt to Equity Ratio diperoleh nilai rata-rata per tahun sebesar $7,72 \% \%$.

2. Kondisi Jawaban Responden Variabel Return on Asset

Berdasarkan data empiris dan analisis data, variabel Return on Asset diperoleh nilai rata-rata per tahun sebesar $0,62 \% \%$.

3. Pengaruh Debt to Equity Ratio Terhadap Return on Asset

Debt to Equity Ratio berpengaruh signifikan terhadap Return on Asset dengan persamaan regresi $\mathrm{Y}=2,109+$ $0,192 X$, nilai korelasi sebesar $-0,778$ atau memiliki hubungan yang kuat dengan kontribusi pengaruh sebesar 60,5\%. Pengujian hipotesis diperoleh nilai $t$ hitung $<\mathrm{t}$ tabel atau $(-3,506<2,306)$. Dengan demikian hipotesis yang diajukan bahwa terdapat berpengaruh negatif signifikan antara Debt to Equity Ratio terhadap Return on Asset diterima.

\section{PENUTUP}

\section{Simpulan}

1. Kondisi variabel Debt to Equity Ratio berdasar pada periode laporan keuangan 10 tahun diperoleh Debt to Equity Ratio rata-rata sebesar $7,72 \%$.

2. Kondisi variabel Return on Asset berdasar pada periode laporan keuangan 10 tahun diperoleh Debt to Equity Ratio rata-rata sebesar $0,62 \%$.

3. Debt to Equity Ratio berpengaruh signifikan terhadap Return on Asset dengan persamaan regresi $\mathrm{Y}=2,109+$ $0,192 X$, nilai korelasi sebesar $-0,778$ atau kuat dan kontribusi pengaruh sebesar $60,5 \%$ sedangkan sisanya sebesar $57,9 \%$ dipengaruhi faktor lain. Uji hipotesis diperoleh nilai $\mathrm{t}$ hitung $<\mathrm{t}$ tabel atau $(-$ $3,506<2,306$ ).

\section{Saran}

1. Perusahaan harus memperhatikan tingkat aktifitasnya, dimana kemampuan perusahaan untuk menciptakan penjualan dengan menggunakan seluruh aktiva yang dimilikinya.

2. Perusahaan harus memperhatikan tingkat profitabilitas, Hal ini masih dapat diperbaiki dengan mengupayakan keuntungan yang maksimal diantaranya mengupayakan tagihan atau piutang yang bermasalah atau semaksimalkan pengembalian secara tepat waktu yang selanjutnya akan menambah jumlah keuntungan. 
DAFTAR PUSTAKA

Agus Harjito \& Martono, (2010) "Manajemen Keuangan" Yogyakarta: Penerbit Ekonisia.

Agus Sartono. (2010). "Manajemen Keuangan Toeri dan Aplikasi”, Edisi keempat, Yogyakarta: Penerbit BPFE.

Algifari. (2015). "Analisis Regresi untuk Bisnis dan Ekonomi”. Yogyakarta: BPFE.

Arikunto, Suharsimi (2014). "Prosedur Penelitian Suatu Pendekatan Praktek". Jakarta: Rineka Cipta.

Bambang Riyanto, (2011). "Dasar-dasar Pembelanjaan Perusahaan". Edisi ke empat, BPFE Yogyakarta.

Brigham, F. Eugene dan Joel, F. Houston. "Dasar-dasar Manajemen Keuangan".Edisi Kesepuluh, JilidI. Salemba Empat. Jakarta : 2008

Fahmi, Irham (2012), "Pengantar Manajemen Keuangan" Cetakan pertama. Bandung: Penerbit Alfabeta.

Harahap, Sofyan Safri. "Analisis Kritis Atas Laporan Keuangan". Raja Grafindo Persada. Jakarta : 2002

Hasibuan, Malayu S.P "Pengantar Manajemen”. CV. Alfabeta. Bandung : 2012

Hidayat, A., \& Sunarsi, D. (2020). FaktorFaktor Yang Mempengaruhi Dana Pihak Ketiga Dan Dampaknya Terhadap Profitabilitas (Survey Pada Bpr Syariah Di Jawa Barat Tahun 2014-2017). Jurnal Proaksi, 7(1), 54-65.

Hushan, Suad dan Enny Pudjiastuti. "Dasardasar Manajemen Keuangan”.Edisi Keenam. UPP STIM YKPN. Jogyakarta:2012

Imam Ghozali (2017). "Aplikasi Analisis Multivariate Dengan Program SPSS". Edisi Kelima. Semarang: Badan Penerbit Undip.

Istijanto (2014) "Riset Sumber Daya Manusia". Jakarta: PT. Gramedia Pustaka

Jasmani, J. (2018). Pengaruh Kinerja Keuangan Terhadap Harga Saham (Analisis Pada Perusahaan Property dan Real Estate Yang Go Public di Bursa
Efek Indonesia. Jurnal Akuntansi Indonesia, 12(2).

Jasmani, J. (2019). The Effect of Liquidity and Working Capital Turnover on Profitability at PT. Sumber Cipta Multiniaga, South Jakarta. PINISI Discretion Review, 3(1), 29-38.

K Nufus, H Supratikta, A Muchtar, D Sunarsi. (2020). Analysis of Financial Performance: Case Study of PT. X Employee Cooperative. Utopía Y Praxis Latinoamericana. Vol. 25. Pages 429444

Kasmir (2010), "Analisis Laporan keuangan”, penerbit raja grafindo persada, Jakarta

Kasmir, (2010). "Pengantar Manajemen Keuangan”, Edisi Pertama, Cetakan kedua, Jakarta: Penerbit Prenada Media.

Kasmir. (2012) "Pengantar Manajemen Keuangan”, Edisi Pertama, Cetakan kedua, Jakarta: Prenada Media.

Kasmir. "Analisis Laporan Keuangan”. PT. Rajawali Persada Jakarta : 2014

Kasmir. "Analisis Laporan Keuangan". Raja Grafindo Persada Jakarta : 2012

Martono dan Agus Harjito, (2011). "Manajemen Keuangan", Jakarta: Penerbit Ekonisia..

Martono dan Agus Harjito."Manajemen Keuangan". Ekonosia.Yogyakarta : 2010

Munawir (2010), "Analisis Laporan Keuangan”, Edisi Ke Empat, Penerbit Liberty, Yogyakarta.

Rodoni, A, Ali, H. "Manajemen Keuangan". Mitra Wacana Media. Jakarta : 2010

S.Munawir."Analisa Laporan Keuangan". Liberty. Jogyakarta:2013 (Edisi Keempat)

Santoso, Singgih (2015). "Menguasai Statistik Multivariat". Jakarta: PT Elex Media Komputindo.

Sartono, "Manajemen Keuangan Aplikasi Dan Teori", Edisi Keempat, BPFE, Yogyakarta, 2008.

Sarwani, S., Akbar, I. R. ., Handoko, A. L. ., \& Ilham, D. . (2020). Pengaruh Pelatihan dan Motivasi terhadap Produktivitas Kerja Karyawan pada PT. Lion Mentari Airlines Bandara Internasional 
Soekarno Hatta Cengkareng. Jurnal Ilmu Komputer Dan Bisnis, 11(2a), 91100.https://doi.org/10.47927/jikb.v1 1i2a.24

Sawir, (2003). "Analisis Kinerja Keuangan dan Perencanaan Keuangan Perusahaan", Cetakan ketiga, Jakarta: Penerbit PT. Gramedia Pustaka Utama.

Siswanto, H, B. "Pengantar Manajemen". BumiAksara. Jakarta : 2011

Sugiyarso, G. dan F. Winarni, "Manajemen Keuangan (Pemahaman Laporan Keuangan, Pengelolaan Aktiva, Kewajiban dan Modal serta Pengukuran

Sugiyono (2017), "Metode Penelitian Administrasi : dilengkapi dengan Metode R \& D”. Bandung: Alfabeta.

Sugiyono. "Metode Penelitian Kuantitatif, Kualitatif dan $R \& D$ ". Alfabeta.Bandung : 2009
Suhartono, A., Jati, W., \& Sunarsi, D. (2019). Pengaruh Earning Per Share Dan Return On Asset Terhadap Harga Saham Pada PT. Bank Negara Indonesia Tbk Periode 2009-2018. Jurnal Manajemen, Bisnis dan Organisasi (JUMBO), 3(3), 182-194.

Yonata, H. .., Setiawan, P., Santamoko, R. ., Ilham, D. ., \& Asdiany, D. . (2020). Pengaruh Kualitas Pelayanan dan Kepuasan Konsumen terhadap Loyalitas Pelanggan pada PT. Satria Antaran Prima. Jurnal Ilmu Komputer Dan Bisnis, 11(2), 2502-2514. https://doi.org/10.47927/jikb.v11i2.1 4

Yusni Nuryani, Denok Sunarsi. (2020). The Effect of Current Ratio and Debt to Equity Ratio on Deviding Growth. JASa (Jurnal Akuntansi, Audit dan Sistem Informasi Akuntansi) Volume 4, Issue 2, Pages 304-312. 